\title{
ON THE FOUNDING OF THE ECONOMETRIC SOCIETY
}

\author{
BY \\ OLAV BJERKHOLT
}

\begin{abstract}
The Econometric Society was founded in December 1930. Invitations for a meeting to establish "an international society for the advancement of economic theory in its relation to statistics and mathematics" had been distributed by Irving Fisher, Ragnar Frisch, and Charles F. Roos, together with a draft constitution. In June 1930, the same instigators had sent a form letter to a list of thirty-one scholars from ten different countries to solicit advice on establishing an international association "to help in gradually converting economics into a genuine and recognized science." The hitherto unpublished responses are set out in the paper. The impact of the solicited advice, not least from François Divisia and Joseph Schumpeter, on the formation of the Econometric Society is discussed in some detail.
\end{abstract}

\section{INTRODUCTION}

The Econometric Society was founded in 1930 with Irving Fisher as the first president. Jan Tinbergen (1973, p. 483) noted that this was the third time in the history of economic science that an attempt was made to introduce mathematical treatment into the study of economic problems: "Unlike the attempts around 1838 (by Cournot) and 1870 (by Walras, Jevons and Menger) which did not succeed, the third 'wave' of quantification was successful."

The name of the society was adopted from the term introduced by Ragnar Frisch in 1926: "Intermediate between mathematics, statistics, and economics, we find a new

\footnotetext{
Olav Bjerkholt, Department of Economics and Frisch Centre, University of Oslo: olav.bjerkholt@ econ.uio.no. The main archival sources used are the Ragnar Frisch papers at the University of Oslo and the National Library of Norway. I acknowledge with gratitude the encouragement and comments over the years from James J. Heckman, Stephen Stigler, and John Aldrich, and the help of Duo Qin in restoring the manuscript of Frisch lectures in 1930. I thank former assistants Ricardo Duque, Frikk Nesje, and Ge Ge, and the editor, Stephen Meardon, and two anonymous referees for pertinent comments and advice.
} 
discipline which for lack of a better name may be called econometrics. Econometrics has as its aim ... to turn pure economics, as far as possible, into a science in the strict sense of the word" (Frisch 1971, p. 386). In his paper, Frisch demonstrated his conception of econometrics as the quantification of economics, theoretically and empirically. A number of papers have given accounts of the founding of the Econometric Society; for example: Charles Roos (1948), Carl Christ (1983), Olav Bjerkholt (1998), Francisco Louçã (2007), and Bjerkholt and Duo Qin (2010). ${ }^{1}$

The seminal idea of an international association and journal of econometrics is known from a letter exchange in 1926 between François Divisia and Frisch (Divisia 1953, pp. 22-30; Frisch 1992, pp. 18-22). The Divisia-Frisch plan that emerged from this exchange was to establish an informal group of mathematical economists-a cercle restraint, as Divisia called it — with a (faint) hope of establishing a journal in the future.

The article aims at shedding more light on two events in 1930, both related to the Divisia-Frisch plan: (1) the solicitation of advice from prominent economists from ten different countries through a letter distributed in June 1930; and (2) the founding of the Econometric Society at the end of $1930 .^{2}$ The founding in December 1930 took place at an "organization meeting" of sixteen persons, who adopted a constitution and elected the first council of the society, as reported in the first issue of Econometrica. It was a somewhat rushed event, not quite a meeting of "founding fathers," as has been stated; it could even be called a proxy meeting at which most of those elected to nurture the newborn society were not present. But it served its purpose.

After the letter exchange with Divisia, Frisch communicated the idea of the DivisiaFrisch plan to four people in his network of scholars in economics and statistics: Ladislaus von Bortkiewicz, Eugen E. Slutsky, Arthur L. Bowley, and the Hungarian statistician Karoly (Charles) Jordan. They all concurred, particularly Bortkiewicz and Slutsky, that the time was ripe for promoting more quantification in economics, inspired by advances in science with mathematics as an indispensable tool. ${ }^{3}$ As Frisch wrote to Bortkiewicz: "I think that the necessity of a quantitative formulation more or less consciously is in the mind of most economists. 'Es liegt in der Luft' as Chuprov said when I had the honor of meeting him in 1924 in Oslo."4 Frisch also quoted Allyn Young: "The growing use of quantitative methods is the most promising development in contemporary economics. But it will prove relatively sterile if it does not lead to a renaissance of theory" (Young 1925, p. 167).

There were, however, nuances of opinion on how to proceed. Bortkiewicz was much in favor of founding an international journal for mathematical economics (even if it meant a zwanglos one), in view of the difficulties of publishing articles with substantial mathematical content in economic journals in Europe (except for Italy). He had less belief than Divisia in the value of informal exchange between the adherents. ${ }^{5}$

\footnotetext{
${ }^{1}$ Many of the secondary sources are marred by incorrect details, some more than others; even the highly authoritative Morgan (1990) states three different founding years for the Econometric Society.

${ }^{2}$ Two key documents from these events are included in an online appendix to this article.

${ }^{3}$ Bowley was Frisch's best choice for an English connection. Edgeworth had died in 1926.

${ }^{4}$ Frisch to Bortkiewicz, December 7, 1926. Chuprov died in 1926.

5"Hingegen verspreche ich mir von einem brieflichen Gedankenaustausch zwischen Anhängern der mathematischen Methode nicht viel. Das wäre etwas unmodern" (Bortkiewicz to Frisch, November 11, 1926).
} 
After this exchange, Frisch felt he had got a mandate of seeking international support to establish a journal. ${ }^{6}$

From the conception of the Divisia-Frisch plan to the founding of the Econometric Society in 1930, informal airing of the plan took place on both sides of the Atlantic. Frisch and Joseph Schumpeter had overlapping visits to the US in 1928. During his visit as Rockefeller Fellow in 1927-28, Frisch canvased universities and research institutions in the US for scholars with an interest in econometrics, without finding many. He wrote a memorandum about establishing an international journal:

Two important features in the modern development of economics are the application of mathematics to abstract economic reasoning ... and the attempt to place economics on a numerical and experimental basis. ... [T] size the quantitative side of the economic problems. ... We consider it essential that the two aspects of quantitative economics should be developed and studied as far as possible jointly as to complementary parts of economics. ... We therefore venture to propose the establishment of an international periodical devoted to the advancement of the quantitative study of economic phenomena, and especially to the development of a closer relation between pure economics and economic statistics.

The essential point should be the quantitative character of the analysis, not the refinement of the mathematics involved. On the other hand, mathematical-economic contributors should feel free to use any mathematical apparatus they might find useful for their purpose. ${ }^{7}$

But nothing came from these preliminary efforts to propagate the idea of econometrics. Scholars proficient in mathematics and interested in the quantification of economics were found mostly in Europe. Irving Fisher stood out in the US as a towering lighthouse for the use of mathematics in economics, but his impressive achievements had not resulted in a mathematical economics school in the US. ${ }^{8}$ Despite Fisher's support, Frisch had found limited interest for the Divisia-Frisch plan in the US when he returned to Europe in April 1928.

Fisher went to great personal expense to have Frisch appointed Visiting Professor at Yale University from February 1930. In the US, he met again with Charles F. Roos, a mathematical economist and student of Griffith Evans, who was employed by the American Association for the Advancement of Science, and had taken great interest in the Divisia-Frisch plan. During Frisch's visit, Roos kept in occasional touch with Fisher and Frisch at Yale about the idea of an association for more scientific economics. Fisher was pessimistic about the prospects.

\footnotetext{
${ }^{6}$ An intriguing record filed by Frisch before departing for the US in early 1927 was titled Letters related to "Oeconometrika," comprising fourteen letters exchanged about the Divisia-Frisch plan between September 1926 and January 1927.

${ }^{7}$ Memorandum by Frisch, typewritten, dated October 1927. Several versions were drafted in 1927-28, also in French, with details about the management of an international journal.

${ }^{8}$ Fisher had made several efforts: for example, a bibliography of mathematical economics in Cournot (1927), his Gibbs Lecture in 1929 on mathematics in the social sciences (Fisher 1930a), and, indeed, his outstanding scholarly work.
} 
Somewhere along the line, Schumpeter had convinced Frisch that an econometric association started in Europe would "remain small and anemic"; it would need "U.S. blood and money for worldwide success and influence" (Allen 1994, 1, p. 269). They both knew that the constituency of mathematical economists was small in the US. A strange bond developed among Fisher, Schumpeter, and Frisch, whose personalities were very different, but held together by mutual scientific admiration and by the common interest in founding and nurturing an econometric association. Frisch had been deeply influenced by Fisher's doctoral dissertation (Fisher 1917), and by Schumpeter's early work. Frisch and Fisher shared an interest in the measurement of marginal utility (Frisch 1932, pp. 5-6). ${ }^{9}$

Sometime in the late spring of 1930, Fisher yielded to the optimism of Frisch and Roos. They decided on a step to move forward with the idea of founding an international association. ${ }^{10}$ They met for a weekend in mid-June 1930 to draw up a list of names of people to solicit for interest in the general idea and for advice. The list comprised thirty-one names (including themselves). They called it the first list; the idea was to proceed to a longer second list if the responses were sufficiently positive.

During the June weekend, they also drafted the solicitation letter, denoted in the following as the June letter, and sent it to the names on the first list. Frisch took it upon himself to put together a digest of the responses to the letter. This was not an easy task, as the June letter was far from well structured. Frisch translated when necessary, and compiled all the responses into the digest of quotes and brief summaries, edited as a synoptic table with additional notes. The digest was completed on October 21, 1931. ${ }^{11}$ The overall plan was, however, cut short, as the solicitation of the first list was followed soon after by invitations for founding the Econometric Society at the end of December 1930.

The names of the first list are set out in section II, and the responses to the June letter that are contained in Frisch's digest are set out in section III. The organization meeting founding the Econometric Society is dealt with in section IV. Section V concludes.

\section{THE FIRST LIST}

Fisher, Frisch, and Roos spent the weekend of June 14-15, 1930, at Irving Fisher's quarters, close to Yale University, to compile the list of names and draft the June letter. ${ }^{12}$

\footnotetext{
${ }^{9}$ On Schumpeter's admiration for Fisher and Frisch, see Allen (1994, 2, pp. 36-37, 64). After 1929 Fisher lost his wealth and public reputation, and was from then on "without honor in his own university ... few ... appreciated the genius of a man who lived among them" (Tobin 2008; cf. Allen 1993). Fisher was resurrected after the financial crisis in 2008 by The Economist, who hailed Fisher for his fundamental works (1930b, 1933) superseding the insight of Keynes.

${ }^{10}$ Fisher reminisced in 1941 about "his own skepticism, only eleven years ago, when Ragnar Frisch and Charles F. Roos suggested to him the formation of the Society" (Econometrica 10 [2]: 183).

${ }^{11}$ International Association of Economists. Digest of Answers to Letter of Invitation to First List. Prepared by Ragnar Frisch, 14 typed pp. (unfit for reproduction), Ragnar Frisch papers, National Library of Norway. The original response letters kept by Fisher are lost.

${ }^{12} \mathrm{~A}$ few days earlier, Frisch wrote to Schumpeter (in Bonn): "You will soon hear from us also regarding another question, namely the plans of establishing an international association of mathematical economics, which we discussed two years ago" (Frisch to Schumpeter, June 11, 1930; emphasis added). For "two years ago," see Bjerkholt and Qin (2010, p. 5).
} 
The list comprised thirty-one names of scholars from ten to twelve countries, mainly scholars well established in academic positions, some retired after long careers.

The list comprised ten Americans: Thomas N. Carver, John B. Clark, John M. Clark, Griffith C. Evans, Mordecai Ezekiel, Irving Fisher, Henry L. Moore, Warren M. Persons, Charles F. Roos, and Henry Schultz.

Henry Moore (b. 1869) was known for impressive pioneering work in confronting theory and data in studies of demand and of business cycles. During visits to Europe, he had attended lectures by Carl Menger and Karl Pearson, and met both Léon Walras and Vilfredo Pareto. Moore had suffered from illness and retired from Columbia University the previous year. John Bates Clark (b. 1849) was the oldest person on the list; he had studied in Germany under Karl Knies of the German historical school, but was nevertheless an outspoken neoclassical economist as professor at Columbia University. Also John B. Clark's son, John Maurice Clark (b. 1884), was on the list. His intellectual luggage combined his father's teachings with a strong leaning towards institutionalism. He had "inherited" Clark Sr.'s professorship at Columbia University.

Thomas N. Carver (b. 1865) and Warren M. Persons (b. 1878) were both Harvard men. Persons had been the key analyst when Harvard started its business of economic forecasting in the early 1920s, and the creator of the A-B-C framework it relied upon while Carver was chair of the Department of Economics (Friedman 2009). At a conference at Harvard in 1923, President Abbot L. Lowell commended Persons and his colleagues for their effort in developing economics from an inexact to an exact science. On the same occasion, Carver spoke of the need to conduct national affairs by scientific economic principles, while "two great countries of the world are on the rocks largely because the men in control were illiterates in economics." 13 But, by 1930, the glory and the self-adulation of the early 1920 s had all gone. ${ }^{14}$

These older-generation American economists were selected by Fisher (b. 1867); they were hardly the kind of founders of an association for mathematical economics Frisch had been looking for, but he liked and appreciated several of them. The younger Americans included Griffith Evans (b. 1887), a mathematician and mathematical economist at the Rice Institute, Houston, who had been the teacher of Charles Roos (b. 1901) and was well connected also internationally. Henry Schultz (b. 1893), at the University of Chicago, was a broadly oriented economist familiar with most statistical techniques in use for analyzing economic statistics, and specialized in demand analysis of agricultural products. Mordecai Ezekiel (b. 1899), of the Bureau of Agricultural Economics, was a leading name among agricultural economists, and shared with them an institutionalist-oriented education and increasing interest in econometrics.

Wesley Clair Mitchell was not on the list of the recipients of the June letter, although he might well have come out on top in a ranking by American professional economists. An inexplicable omission was Harold Hotelling (b. 1895) from Stanford University.

\footnotetext{
${ }^{13}$ Harvard Crimson, October 22, 1923.

${ }^{14}$ Persons conjectured in 1930 that normal conditions would be restored by the first quarter of 1932 (Glasner 1997, p. 527). The methodological weaknesses of the "Personsche System" was exposed by the German-Russian statistician Oskar N. Anderson (1929). Persons had edited Harvard's Review of Economic Statistics since the first issue; after 1930, it was transformed into a regular journal (only the title remained for another decade as a memory of its origin in reporting economic statistics).
} 
Hotelling had visited Ronald A. Fisher at Rothamsted but was back in the US from the beginning of 1930. Frisch had known Mitchell, Hotelling, and Schultz since 1927.

The second-largest group comprised five Italians: Luigi Amoroso, Corrado Gini, Umberto Ricci, Alfonso de Pietri-Tonelli, and Gustavo del Vecchio. Italy was a strong nation in economics, not least in mathematical economics. Schumpeter observed that Italian economics in 1914 was second to none, and that, "independently of Pareto, Italian economics attained a high level in a variety of lines and in all applied fields" (Schumpeter 1954, p. 855). Gini's (b. 1884) eminence was in demography and statistics applied to economics and social science in general, more than in economic theory. Amoroso (b. 1886) was a leading follower of Pareto, and known for work in mathematical economics, as were the other three men, del Vecchio perhaps less than the others. Italy was under fascist rule, and corporative economics was promoted. Gini in particular had been close to Mussolini in the mid-1920s and deeply involved then with fascist ideology. Amoroso was also involved but that didn't appear to affect his work. Ricci (b. 1879) and Pietri-Tonelli (b. 1883) were opposed to fascism; Ricci chose exile in Egypt from 1931. Del Vecchio (b. 1883) had also yielded to the pressure of joining the party.

The four from France comprised Clément Colson (b. 1853), François Divisia (b. 1889), Jacques Moret, and Jacques Rueff (b. 1896). Colson had been the teacher of Divisia and Rueff (and also of René Roy) at l'Ecole Polytechnique. Colson was the leading name in mathematical economics in France; his students showed him great reverence. He was, unlike Clark Sr. of nearly the same age, active and far from outdated as a scholar to solicit for advice. Divisia had recently published a significant monograph (Divisia 1928). Jacques Moret was associated with Revue d'économie politique and the author of a well-known book on the use of mathematics in economics (Moret 1915). He had translated Irving Fisher's 1892 dissertation (Fisher 1917).

Only three names were included from England: Arthur L. Bowley (b. 1869), Arthur C. Pigou (b. 1877), and John Maynard Keynes (b. 1883). Bowley was the type of scholar in background and interests whom Frisch wanted to enlist in the econometric movement. The attempt to involve Pigou was unsuccessful; he did not respond at all. Keynes was an obvious choice on a list of prominent economists, but did not show much interest in the venture.

From Sweden, Gustav Cassel (b. 1866) and Bertil Ohlin (b. 1899) were on the list. Cassel came to economics from mathematics, and became internationally known in the 1920s as a League of Nations economic expert and author of The Theory of Social Economy (1924). Cassel's long-time rival in Swedish economics, Knut Wicksell, had died in 1926. The younger generation, the Stockholm School, including Ohlin, preferred to build on Wicksell. Cassel's fame had eclipsed while Wicksell's name was still on the rise, not yet translated into English. The pompous Cassel, however, wanted nothing to do with econometric ideas. Ohlin had studied at Harvard in the early 1920s, and would join the Econometric Society with some other Stockholm School economists.

Two outstanding scholars on the list were the Berlin professor Ladislaus von Bortkiewicz (b. 1868), who even had corresponded with Walras about mathematical economics, and the brilliant Eugen E. Slutsky (b. 1868) at the Conjuncture Institute in Moscow. ${ }^{15}$

\footnotetext{
${ }^{15}$ None of them came to play any role in the Econometric Society; Bortkiewicz lived for only one more year and Slutsky never joined.
} 
Vienna was known for both its economists and its mathematicians, although not for mathematical economics, but there was an emerging interest there too. The Austrian School economist Hans Mayer (b. 1879) was the successor of Friedrich von Wieser and influential at the University of Vienna and as editor. ${ }^{16}$ Mayer understood mathematical reasoning, but was not a practitioner.

Also on the list were: from Norway, Ragnar Frisch (b. 1895); from Denmark, Harald Westergaard (b. 1853), a renowned statistician who earlier in his life had engaged in economics; and from Poland, Wladislaw Zawadski (b. 1885), known for a monograph on the use of mathematics in economics (Zawadski 1914) in the Paretian tradition.

Last, but not least, Joseph A. Schumpeter (b. 1883), Bonn University, had expressed great interest in the Divisia-Frisch plan, and discussed it with Frisch and Fisher in 1928. No one, not even Schumpeter, knew in 1930 that his future would be in the United States.

The first list comprised several links to the pioneering mathematical economists; some had known Walras, such as Henry Moore and Bortkiewicz, while others had been students of Vilfredo Pareto, Francis Y. Edgeworth, Alfred Marshall, Friedrich Wieser, or Knut Wicksell. But the selection of the names was hardly the first choice for an association for mathematical economics. It can be viewed as having an emphasis also on well-known, highly respected scholars even without mathematical proficiency. The purpose of the list was, after all, to serve as an advisory group. Fisher (and Schumpeter) knew that more than enthusiasm was needed to succeed in an ambitious venture.

\section{THE JUNE LETTER AND THE RESPONSES TO IT}

Over the weekend, the three instigators prepared the June letter on the organization of an international association and sent it to each person on the list. ${ }^{17}$ (As mentioned above, the responses to the letter quoted in this section are those compiled by Frisch for his digest.) Looked at in retrospect as a document that served to prepare the Econometric Society half a year before the society was founded, it is striking that the term econometric did not appear in it. ${ }^{18}$ It was only obliquely present in the proposed name of the association's journal as Oekonommetrika. ${ }^{19}$

The letter was an enquête but a poorly structured one. A number of different questions were posed. Cassel and Pigou did not respond at all. Henry Moore merely stated his regrets that he had to decline to help form the association because of ill health. (The three instigators did not submit their own views.)

\footnotetext{
${ }^{16}$ Hans Mayer joined the Econometric Society in 1931. At the end of the 1930s, several former students and colleagues were in exile (or dead), and Mayer had joined the Nazis as his way of survival; see Leonard (2010, pp. 83-91) and Klausinger (2015).

${ }^{17}$ The June letter (with the first list) is reproduced in an online appendix to this article.

${ }^{18}$ The term econometrics did not appear in print apart from Frisch's 1926 essay until after the Econometric Society was founded.

${ }^{19}$ The June letter is cited in Bjerkholt (1998, pp. 36-37), Divisia (1953, pp. 26-27), and Louçã (2007, p. 28); the latter stated incorrectly that it was an invitation to a "foundational meeting of the Econometric Society."
} 
The June letter stated the purpose right away: "to ask your opinion as to a project we have been considering, namely the organization of an international association for the advancement of economic theory. ... [T] he chief purpose of such an association would be to help in gradually converting economics into a genuine and recognized science." The letter asked whether such an association was desirable.

The Europeans on the list were all able to follow a formal mathematical argument, even if they were not proficient mathematical economists. With the exception of Keynes, those who responded were overwhelmingly positive. Colson believed "in the utility of the association," Zawadsky found the proposal "extremely desirable," Mayer was "delighted that a purely theoretical and disinterested organization in economics will be established," Ohlin was "in utter sympathy with the ideas and views behind your letter," and so on. Schumpeter's response suggested that he read it as a proposal that would be helpful to connect mathematical economists who, after all, were few and far between: "I believe that such an organization could do much to coordinate the efforts of many workers the fruits of which are half lost by their isolation. In fact, that it would meet a want which all of us feel keenly at times." Keynes's response was noncommittal and not without a touch of arrogance: "I cannot see what purpose such an association would serve unless it were to publish a journal ... I regard the multiplication of associations to be an evil, unless they serve a clear and definite purpose."

The American responses also embraced the association in laudatory terms. The neoclassical and non-mathematical John B. Clark found the proposal "profoundly interesting." His son, the institutionalist and non-mathematical John Maurice Clark, seemed less enthusiastic: "I must admit that there is a place for an international organization of persons who are doing serious work in the field of theory."

The main programmatic massage was presented as simplistic history:

As you know, the quantitative movement in economics started on an a priori basis through the introduction of mathematics into economic theory. Afterwards and independently, empirical studies in mathematical statistics were made. Still more recently, a beginning has been made to bridge the gap between these two approaches. These attempts at putting economics on a scientific and quantitative basis by introducing numerical and statistical observations into the theoretical structure we consider as one of the most promising developments in modern economics, and one to which the association should give considerable attention. ${ }^{20}$

The June letter stated proposed eligibility rules for membership:

According to our present ideas, membership should be subject to election by general vote of the association and should be limited to those who

(a) are thoroughly familiar with general economic theory,

(b) have a working knowledge of mathematics as applied to economic theory and statistics,

(c) have some knowledge of accounting,

${ }^{20}$ The "bridge the gap" simile passage reappeared later as "the bridge that was never completely built" (Haavelmo 1944, p. iii). 
(d) have published an original contribution to economic theory or to the analysis of such economic statistics or accounting as have a definite bearing on problems in economic theory.

The first sentence suggested that the proposed association was not an ordinary membership organization, but more like an academy with new members voted in if they were found eligible.

Expressions such as "thoroughly familiar" and "working knowledge of mathematics" in (a) and (b) were unavoidably open to interpretations. The emphasis on mathematics in (b) called forth reactions from some of the Americans. Requirement (c) on accounting stuck out as something not really belonging on the list. Divisia called it "accessory" in his response.

In addition to the positive requirements, the June letter singled out in an odd paragraph two groups of practitioners not welcomed as members:

We believe that the association should not include those who have merely treated economic problems empirically, without reference to fundamental theoretical principles. If you and the others consulted are in sympathy with us in laying down this policy, mathematical statisticians as such will not be included. They will only be included if they satisfy all the requirements (a) to (d). In practice, the line may be difficult to draw. On this we would like to have your judgment.

Slutsky's response to the June letter was a single remark related to this exclusion clause: "My name ought to be excluded from the list. ... I feel myself at present to be a mathematical statistician more than an economist." Frisch, who had great admiration for Slutsky, made a mental note to inform Slutsky that there was no problem. ${ }^{21}$

The June letter's question about the adequacy of the requirements caused a disparity in the responses between the econometric viewpoint-the Frischian view of a science of economics penetrated by mathematics, as expounded by Colson-and that of the American institutionalists. Colson, the doyen of the French mathematical economists, set out his "conviction of the absolute necessity of a profound familiarity with mathematical formulae and with their application to the experimental sciences in order to really understand the material dependency between economic phenomena." Contrary views emanated from J. M. Clark: "it seems to me that [the association] should not select its membership by a test of fitness for the mathematicalstatistical type of work alone, nor set up a journal committed to giving this type of work dominant place"; and from Persons: "I would prefer ... an association ... in which the members would be elected but one in which the specific qualifications for membership would not be defined."

There was undeniably a Europe-US divide in mathematics at this time. Mathematics in the US was underdeveloped in comparison with Europe. The greatest name in American mathematics in the nineteenth century had been Josiah Willard Gibbs, who made important contributions also to physics and chemistry. Gibbs had been the teacher of Irving Fisher (and of Edwin B. Wilson). The sparsity of mathematical economists in the US can be related to the Europe-US gap in mathematics and to the dominating position of institutionalism.

\footnotetext{
${ }^{21}$ See section V on Slutsky's predicament.
} 
Colson offered viewpoints, both principled and pragmatic, with regard to the delimitation of eligibility for membership:

It is obvious that we must not admit to the society other members than those who are capable of appreciating and applying the intimate connections that link any really scientific study of economic phenomena (and also any phenomena susceptible of measurement) to mathematics. But on the other hand, we ought not to exclude those scholars who have not published works applying directly mathematics to economic phenomena if we want to have an association large enough to exert a real influence and to maintain a journal.

In France we have very few mathematical economists, although Walras and Cournot were our compatriots. The teaching of political economy is unfortunately under the faculties of law and until the last few years the use of mathematics in economic works was not looked upon very favorably. However, I notice that during the last few years a certain tendency among the most intelligent of our jurist-economists to admit this use and to regret that it is not mastered. ... That is why I would not exclude those who are only capable of understanding mathematical works without being able to take active part in the work. Of course this does not mean that the society should be open to people who are only sympathetic to the movement without being capable of following the mathematical works.

In France it was the high-level engineering schools that produced the mathematical economists, not the universities. ${ }^{22}$ Thus, Italy, rather than France, had established the strongest tradition in mathematical economics at (some of) the universities.

Henry Schultz commented that the requirements were not given an adequate formulation in the letter, but that he found it difficult to substitute a better one. He added: "It is well to recognize that the fundamental theoretical principles of economics are not very clear and that they do not possess the same heuristic properties of the general principles of mechanics and biology."

Bortkiewicz made a distinction between "mathematical" and "quantitative": "It seems to me to be quite legitimate to emphasize the quantitative character of economics. But quantitative is not necessary mathematical." He cited Marshall's statement that Ricardo had no mathematical training, "but his instincts were unique; and very few trained mathematicians could tread as safely as he over the most perilous courses of reasoning" (Marshall 1936, app. L, p. 836). Bortkiewicz suggested accordingly broader requirements for eligibility, "something like, a thorough familiarity with theory coupled with the conviction that the quantitative analyses of economic relations are of fundamental importance." Westergaard expressed a similar view.

Schumpeter had embraced the Divisia-Frisch plan about promoting mathematical economics, while the June letter had given the impression of conflated ideas. He cut through to the core of the June letter:

\footnotetext{
${ }^{22}$ Colson was educated at l'Ecole polytechnique and at l'Ecole nationale des Ponts et Chaussées, as was Divisia, who succeeded Colson as professor at l'Ecole polytechnique. Both of them contributed towards strengthening economics at these schools.
} 
I cannot too strongly urge that a clear choice should be made between two possible policies: Either strictly organ of mathematical economics or all economists of standing. I should not trust too much to the 'vote of members' lest the true aims might be lost sight of. Either the association is to be strictly the organ of those who believe that no truly exact theory is possible, without mathematics. Or, it is to be the organ of, if possible, all theorists of standing. ${ }^{23}$ Both policies are defensible, but it would be a source of difficulties if you failed to adopt one of them. The first of these difficulties presents itself at the very outset: If I look over the men whose names are on p. 2 of your letter, I see several among them, who, whilst theorists of eminence are yet entirely nonmathematical and even opposed to the use of mathematics: e.g. I esteem, and personally like Professor Mayer; I am glad therefore, that you have included him; but if his name should appear among the original members, it is not easy to see on what principle it will be possible to exclude such men as Fetter and Taussig or Spiethoff. To avoid needless offence, you will be driven to including them; and you will finally have an association consisting undoubtedly of economists of rank, but of whom a majority might, and probably will, be strangers to the aims described. I am not, let me say it once more, arguing against this. ... All I say is that if this be intended, leading men of all scientific parties ought to be included, and smaller men ought to be excluded even if they happen to have written a paper on mathematical theory. If this, on the other hand, is not your intention, the requirement of knowledge of mathematics ought to be interposed very strictly — or else there will be offence, and much unnecessary antagonism from many worthy men.

Schumpeter expressed concern that the requirements in practice might be watered out. Divisia was less worried, and found the requirements for eligibility "quite appropriate. Some people may find that they are too severe, but I think that severity is indispensable in order that the association should not deviate from its object."

Two other remarks in Schumpeter's thoughtful response are worth noting: "The right to propose or vote on the eligibility of members should be confined to a small group; else the qualifications will fatally approach zero point before long." The statement can be read as Schumpeterian elitism but was sound advice in pursuance of the Divisia-Frisch plan. Frisch and Schumpeter saw eye to eye on the issue, and in the early years after the Econometric Society had been founded, they exerted joint efforts to keep the number of elected fellows low.

The other Schumpeter remark was even more important. In his digest, Frisch wrote it down as "Suggests later a 2nd class of members, admitted freely." It is not crystal clear what Schumpeter actually stated, but a reasonable interpretation is that Schumpeter argued that the proposed association, if it came to anything, ought to allow a second class of members for whom the membership requirements did not apply. He was the only person to suggest anything like this. Schumpeter's suggestion was shortly afterwards incorporated in the tentative draft constitution Frisch prepared for the organization meeting in December 1930, indicating that this point must have been discussed and agreed among Fisher, Frisch, and Schumpeter in the interim between the June letter responses and the November invitation.

\footnotetext{
${ }^{23}$ Schumpeter had noted the duality in the invitation letter, which Bortkiewicz did not do. See the discussion of his reaction in section $\mathrm{V}$ below.
} 
Bowley's only comment on the eligibility issue was that requirement (b) on mathematics might be dropped and the word "modern" added to requirement (a).

Several reacted to the requirement of knowledge of accounting, suggesting either that it be removed (Evans, Bowley, Westergaard, Divisia, Schumpeter), replaced with a requirement of experience with statistical data (Ezekiel, Amoroso), or possibly merged with another requirement (del Vecchio, Colson). Schumpeter remarked that "emphasizing accounting carries with it—unjustly perhaps-an undesirable flavor of "subalternity.",

The passage in the June letter about eligibility for membership had an additional specific point as to whether experience with statistical data ought to be added as a requirement. This turned out to be quite divisive among those who chose to respond to it. Divisia addressed it as follows: "I am not in favor of adding the condition about experience in handling statistical data. I question very greatly the value of certain statistical methods now in vogue. My objection against them is primarily that they are not animated by the theoretical spirit and I would not like to see them put on the same footing as theory itself." Frisch was hardly opposed to experience in handling data, but would have agreed with Divisia that this should not be mandatory. Those who supported this requirement were Carver, Ezekiel, and Westergaard, while those who were opposed were Amoroso, Ricci, Divisia, Moret, Schumpeter, and Ohlin.

The June letter's suggestion of an "international association for advancement of economic theory" was endorsed by Schumpeter as the name for the association. Divisia had thought deeper about the name issue:

If the association takes such a name there would be many economists who would want to be members but do not meet the requirements. Would it be possible to refuse them without hurting them and without seeming to pronounce a sort of exclusion against them, and without having the appearance of wanting to monopolize economic theory?

I fear that if we don't watch our step in this question we would risk provoking in France and no doubt also in other countries regrettable confusions. It seems to me that we ought above all to attempt to advance in an atmosphere of peace; our association has only one object, which is thoroughly disinterested, to favor the scientific work of the advancement of the association. I do not think that we ought to risk at any price being taken for a machine of war, and it seems to me that this pitfall is rather easy to evade.

His suggestion was for the name to be the International Association for the Advancement of Econometric Studies.

The June letter outlined the contents of the journal of the association (if it were to be) and named it Oekonommetrika (with Economic Theory and Economic Science as alternatives). The outline of the contents left no doubt that it would be a journal wholly devoted to mathematical economics. The journal would be

(1) reviewing and abstracting the more important mathematical economic works, both ... currently published ... and the outstanding works of the past,

(2) furnishing biographical notes regarding mathematical economists of the past,

(3) preparing a complete ... bibliography of mathematical economic literature.

The major part of the journal would be devoted to mathematical economic contributions, while non-mathematical papers with significant contributions to economic theory or to the numerical verification of economic theory might be accepted. 
The invitation to name a journal for which there was no inkling of a financial foundation invited a free run for the fantasy. While Ezekiel outright doubted the desirability of another journal, Ricci found Oekonommetrika as a "rather funny" name for a journal, and suggested a more conventional name, as also did Gini, Pietri-Tonelli, and Bortkiewicz. Amoroso, Schumpeter, and Divisia embraced Oekonommetrika, the latter two with different spelling; Schumpeter wanted, on philological grounds, Oekometrika, while Divisia again had thought deeper about it. He dismissed at the outset the June letter's two alternative proposals:

I think that the name Economic Science is very dangerous. It seems to indicate that we want to monopolize economic science and that we are the only ones who represent the true economic science. This may perhaps be at the bottom of our thoughts but I do not think that the time has yet come to proclaim it. ... [I]t seems to me that we ought to present ourselves as cultivating a certain method of economic research because we think they are good, and not because we have the pretention to decide definitely the question of knowing whether other methods may also be interesting.

The name Economic Theory ... I fear ... would be misinterpreted as indicating an aim only of elaborate theories without any aim at concrete verification and applications to practice. I would therefore prefer the word that Ragnar Frisch has coined, and coined very fittingly, i.e. Oekonommetrika.... [I]t characterizes the 'econometric' tendency, and simply in order to favor the development of this tendency it is very important to give a name to it.

I have no reservations to make except as to the orthography. ... The original way of spelling the word, namely Econometrica is less correct but very much more elegant, it seems to me, and more beautiful. ... Econometrica has also the advantage of giving the current language the adjective econometric ... which seems to me indispensable.

Econometrica would also have the advantage of being close to the orthography of the English and the French, which are the two international languages. As to the proposal of writing two m's in the word econommetric, I am the one who suggested that this would be the etymologically correct solution, but I am not at all in favor of this way of spelling it. It is not beautiful. I propose calling the new journal Econometrica.

Divisia's revival of the journal name coined in the exchange between him and Frisch in 1926 and his proposal of using econometric also in the name of the association clinched the name issue both for the association and the journal. ${ }^{24}$

Nothing was mentioned in the June letter about meetings. Ricci brought it up anyway, stating with great foresight from his exile in Egypt that "meetings of members will be in future very useful."

The June letter sketched the further plan of sending a similar letter to a larger group, and asked for names. Only fifteen responded, mostly by proposing persons from their own country or even closer to themselves. Evans and Mayer took a broader view; both proposed Jan Tinbergen, Wassily Leontief, and members of the New Vienna School ${ }^{25}$

\footnotetext{
${ }^{24}$ The name of the journal was not stated in the constitution adopted in 1930 and not decided until after Frisch had been elected editor in 1932; see Bjerkholt (2013, p. 7).

${ }^{25}$ On the New Vienna School, see Montesano et al. (2014, p. 554).
} 
(Ewald Schams, Leo Schönfeld, Paul Rosenstein-Rodan); Mayer proposed also Friedrich Hayek, Gottfried von Haberler, Oskar Morgenstern, and Hans Staehle; and Evans threw in American heavyweights Edwin Bidwell Wilson and Harold Hotelling. Costantino Bresciani-Turroni was proposed by no less than four. Schumpeter proposed his Bonn colleague Erwin von Beckerath and two younger economists in Germany: Erich Schneider and Jacob Marschak.

The June letter asked explicitly if the respondents considered themselves eligible for membership according to the conditions stated. Schultz answered with hidden irony that "with lenient judges I might just squeeze through." John Maurice Clark seemed very interested in becoming member of the association, despite being "reluctant to lend support to the complete capturing of 'theory' by the mathematical-quantitative method." 26

While editing the responses into the digest, Frisch noted that some of the responses were of much greater interest than others, and remarked in the digest that there was a group of eleven persons who could be taken as a "nucleus giving advice on the next move to be made." The group comprised, in addition to the instigators-Fisher, Frisch, and Roos-eight others, chosen from their responses: Amoroso, Bortkiewicz, Bowley, Colson, Divisia, Ricci, Schumpeter, and Zawadski.

The June letter was not very explicit about the further path towards founding an association. There was mention in one passage of charter members with "undoubted qualifications" without further clarification. The implied meaning here was that a suitable number of charter members would have to be signed up before the founding of an association. The charter members would be the founding members. But this is not what happened, as will be apparent in the next section.

\section{THE ORGANIZATION MEETING OF THE ECONOMETRIC SOCIETY}

The invitation to found the Econometric Society, also signed by Fisher, Frisch, and Roos, was sent to a list of eighty-three names. ${ }^{27}$ There is little direct evidence of what happened among the key instigators between the completion of Frisch's digest on October 21, 1930, and November 29, when the invitations to the organization meeting were dispatched. But the documents reveal significant differences between the outline of the association in the June letter and the proposed Econometric Society in the tentative constitution attached with the November invitation. ${ }^{28}$

These differences, and indeed the decision to have an organization meeting, which was not mentioned as a possibility in the June letter, are likely to be the outcome of exchanges among Frisch, Schumpeter, and Fisher, some of which may have taken

\footnotetext{
${ }^{26} \mathrm{John}$ Maurice Clark became an early member of the Econometric Society, although never one who, by Schumpeter's words, believed that "no truly exact theory is possible, without mathematics." Frisch and Clark had a heated exchange in the Journal of Political Economy (1931-32), which revealed that Clark missed points in Frisch's relatively simple mathematical reasoning; see Chipman (1998, pp. 88-90).

27"The Invitation for the Organization Meeting November 29, 1930 and the List of Addressees" is posted on https://www.econometricsociety.org/society/about (accessed 26 December 2016).

${ }^{28} \mathrm{~A}$ facsimile of the tentative draft constitution is given in an online appendix to this article.
} 
place at a weekend in New Haven, as foreshadowed in a letter to Frisch from Schumpeter, sent from the Norddeutscher Lloyd steamship Karlsruhe:

\begin{abstract}
I have to apologize to you on a score of heads, especially for not functioning in the matter of our oecometric society, which we had so many pleasant talks about at Harvard in 1928. I am very glad that you have now secured a more efficient ally and shall be happy to enlist as a modest private soldier under the new banner. Now I hope to be in Cambridge by Sunday 21st, to stay till about Xmas (for the first Harvardian term). I shall be pretty much in harness, but I attach the greatest importance to meeting you. Some early weekend I want to run down to New Haven to pay my respects to our eminent friend Fisher, and to see you and hear about your things. (Schumpeter to Frisch, September 19, 1930) ${ }^{29}$
\end{abstract}

Schumpeter had been enthusiastic about the Divisia-Frisch plan since 1928, but had so far taken little part in furthering it, beyond the "pleasant talks" at Harvard (Bjerkholt and Qin 2010, p. 5). The "more efficient ally" was, of course, Fisher. But now Schumpeter's time had come. He played a major role in the change of direction and pace after the June letter up to his masterly chairmanship of the organization meeting at the end of the year.

The November invitation briefly explained that the responses to the June letter were so encouraging that it seemed desirable to move directly to the formation of the society, dropping the solicitation of the second list. This is totally unconvincing, an argument made up to explain the shortcutting of the original plan by proceeding to the founding without further solicitations and the signing up of charter members. The real reason is likely to have been that both Frisch and Schumpeter would soon leave the US and no one knew when they both could be with Fisher in the US again.

The November invitation was about founding a "society," not an "association," as in the June letter. This is only a tiny detail in the overall picture; the change of term was not noted. It may well have been Schumpeter's suggestion. The November invitation did not introduce "Econometric Society" as the name for the society to be founded. Instead, it had a wonderful passage that argued that the name of the society ought to "indicate quite clearly the specific object which the society has in view," and that if the society was formed with a scope as suggested, "it seems advisable to coin a word, since no single word will connect exactly the idea. ... [W] have been unable to find a better word than econometrics." The draft constitution attached with the November invitation used, however, "Econometric Society" as if the name already had been adopted.

A crucial change from June to November was the reformulation of the scope of the society from "advancement of economic theory" to "advancement of theory in its relation to statistics and mathematics." This was the magic formula! It is indeed strange that Frisch went along with the bland formulation of the June letter. The November reformulation certainly conveyed more of the spirit of the original Frisch 1926 definition and in an improved version. ${ }^{30}$

The November invitation letter did not contain anything else that was new, relative to the June letter; the changes were all in the draft constitution. As pointed out in

\footnotetext{
${ }^{29}$ The weekend in New Haven is likely to have taken place in late October or November, and possibly as mentioned in Frisch (1951, p. 88) and Allen (1994, 2, p. 37).

${ }^{30}$ Frisch's original formulation led to less fortunate renderings of econometrics as a "union of mathematics and statistics with economics," as in Morgan (1990, p. 2).
} 
section III, an important change was due to Schumpeter's somewhat cryptic response remark of " 2 nd class of members." The draft constitution introduced a two-tier society with "regular members" and "fellows," an idea completely absent in the June letter. Scrutiny reveals that the eligibility requirements for membership in the association in the June letter were practically identical with the eligibility requirements for fellowship in the draft constitution. The November constitution, however, allowed regular members in addition to fellows. All power was vested in the fellows; the regular members had no say in the society's affairs. Still, the addition of regular members was a key to the society's success.

From Schumpeter's point of view, this was a way of preserving the purity of the scope of the society. Interest in becoming a member of a (closed) society with membership decided by majority vote would, in his view, unavoidably lead to watering out of the requirements. With the two-tier construction in the tentative constitution and appropriate rules for fellowship elections, a defense line could be established. Fisher and Frisch seem to have become convinced of the sensibility in Schumpeter's view, and Frisch drafted the constitution accordingly.

The venue for the organization meeting was specified in the invitation to coincide with the joint annual meetings of the American Economic Association, American Statistical Association (ASA), the American Mathematical Society (AMS), and sections A and K of the American Association for the Advancement of Science (AAAS), and the time was set to December 29, 1930. On that day sixteen persons, no more, no less, turned up at Hotel Statler in Cleveland for the organization meeting, which was called to order at 8:00 p.m. It was a low-key event, hardly announced at all apart from the invitations, fitted unobtrusively into a vacant room.

Of the eighty-three persons on the invitation list, including the three instigators, forty-eight resided in Europe, thirty-two in the US (including some visiting Europeans), one in China, one in Japan, and one in Brazil. It was not surprising that no one came to Cleveland from overseas expressly for the meeting. The invitation guardedly expressed the hope that "the formal enactment of the society will, in all probability, take place"!

Sixteen persons may seem a poor turnout from a list of eighty-three, even when admitting that those who lived in Europe or even further away would probably not have considered crossing the ocean to be present. The turnout was, in fact, worse than the crude numbers indicated, as scrutiny reveals that only ten of the sixteen were on the invitation list: Ragnar Frisch, Harold Hotelling, William F. Ogburn, J. Harvey Rogers, Charles F. Roos, Josef Schumpeter, Henry Schultz, Walter A. Shewhart, Ingvar Wedervang, and Edwin B. Wilson. The other six were three excellent mathematiciansKarl Menger, Oystein Ore, and Norbert Wiener-attending the AMS meeting, and three prominent members of ASA, Frederick C. Mills, Malcolm C. Rorty, and Carl Snyder.

We can tentatively reconstruct how it happened that the non-invited six came to attend the organization meeting. On December 28, the American Mathematical Society held an afternoon session, jointly with the ASA, whose meeting had opened the same day, and also with sections A and K of the AAAS.

The joint session took place in Hotel Statler. The three speakers were Griffith C. Evans, on a theory of economic crisis with Henry Schultz as discussant; Ragnar Frisch, on decomposing empirical time series with Oystein Ore as discussant; and Harold Hotelling, on recent improvements in statistical inference with Walter Shewhart as discussant. All three speakers with discussants reappeared at the organization meeting a couple of hours later. Ore was professor in mathematics at Yale, specially invited to 
give a lecture at the AMS meeting, and a friend of Frisch from student days in Oslo. Karl Menger, who visited the US in 1930-31 on a Rockefeller fellowship, was, like Ore, also in Cleveland, invited to give a lecture at the AMS meeting.

Norbert Wiener took part in the AMS meeting, as did also Frisch and Roos. Malcolm Rorty was the current president of the ASA and naturally was present at the joint session. Carl Snyder was a former president, while Fisher, Ogburn, and Mills were the next three presidents of the ASA. Edwin B. Wilson of Harvard, who was the ASA president in the preceding year, had been a student of Josiah W. Gibbs, and indeed gave the Eighth Gibbs Lecture in Cleveland on December 30.

Thus, it seems that most, if not all, of those attending the organization meeting in the late evening of December 29 had good reasons for attending the joint session and the mingling of people after it ended, just a couple of hours before the organization meeting in the same building. Even with the six "uninvited" persons, the organization meeting wasn't exactly crowded. Only a few of the approximately thirty-plus American residents on the invitation list came to the organization meeting.

That the small organization meeting of sixteen persons comprised five of the ASA presidents from 1928 to 1934 (six if Fisher is included) might, to a casual observer, suggest that the Econometric Society was a "child" of the ASA. But the amassment of past, current, and future ASA presidents at the founding of the Econometric Society was rather due to the difficulties in finding Americans interested in the scope of the society, and, perhaps even more, that the professional friends Fisher still retained were not least to be found among the leading members of the ASA.

It is not unusual to come across summary accounts of the foundation of the Econometric Society denoting the sixteen persons present at the organization meeting as the bold "founding fathers" of the society, or speaking of the organization meeting itself in solemn terms as the "inaugural conference of the Society" (Louçã 2007, p. 31). Such characterizations are somewhat misleading. But what were the sixteen persons gathered in the meeting room at the Statler Hotel the night of December 29, 1930, if they were not founding fathers? The report from the meeting published in Econometrica in its first issue in 1933 called them simply the "organizing group."

According to the report from the organization meeting (Econometrica 1: 71-72), Frisch had circulated a draft of a tentative constitution "based on ideas which had been obtained in an extensive correspondence carried on by himself, Professor Fisher, and Professor Roos, with economists and statisticians throughout the world." Schumpeter was elected chairman of the meeting and Roos as recorder. The report further conveyed that all those present took an active part in the discussion and revision of the draft constitution, although no discussion details were given. This part of the proceedings lasted for most of the first two hours of the meeting before a revised constitution was voted upon. Schumpeter's motion that the society should be considered founded was then accepted unanimously.

The election of the president (Irving Fisher) and the council members took another thirty to forty-five minutes. Then the first meeting of the Econometric Society was adjourned. The report was not explicit about any controversy at the meeting, neither on the constitution nor on the elections. ${ }^{31}$

\footnotetext{
${ }^{31}$ Hendry and Morgan (1995, pp. 4,8) oddly assert that Schumpeter was the first president and commend him for his presidential address, a feature Econometric Society did not introduce until decades later.
} 
The council (which was an executive committee, not an advisory council) elected at the meeting in 1930 comprised the following ten members from eight different countries: ${ }^{32}$

Irving Fisher, Yale University

Luigi Amoroso, University of Rome

L. v. Bortkiewicz, University of Berlin

A. L. Bowley, London School of Economics

François Divisia, Ecole Nationale des Pont et Chaussées, Paris

Ragnar Frisch, University of Oslo

Charles F. Roos, Smithsonian Institution Building, Washington

Josef Schumpeter, University of Bonn ${ }^{33}$

E. B. Wilson, Harvard University

Wl. Zawadski, University of Wilno

The list differed little from Frisch's "nucleus" list (see end of section III): Colson and Ricci were dropped and Wilson was added. Frisch was, at the end of the day, uncertain whether Wilson had been duly elected, as Wilson left before the election was finished (see section V).

The meeting made no changes in the draft subtitle of the Econometric SocietyAn International Society for the Advancement of Economic Theory in its Relation to Statistics and Mathematics - which ever since has been rendered on the front cover of Econometrica.

The first part of the constitution, on the Scope of the Society, underwent only minor linguistic improvements. But it was discussed, at least its key sentence: "Its main object shall be to promote studies that aim at a unification of the theoretical-quantitative and the empirical-quantitative approach to economic problems and that are penetrated by constructive and rigorous thinking similar to that which has come to dominate in the natural sciences." Frisch later gave Divisia the following account:

It is true that there was at the beginning of the meeting some confusion particularly in regard to the interpretation of the term 'quantitative', some people seeming to understand by this term simply 'statistics'. But after a long and very elucidating speech by Schumpeter who emphasized that economic theory must be at the basis of the work which the Society should have in view, this question was cleared up in a way which I think is definitive. I attach particular importance to the fact that after Schumpeter's talk the American members dropped Wesley C. Mitchell as their candidate for Council membership. (Frisch to Divisia, July 28, 1931) ${ }^{34}$

\footnotetext{
${ }^{32}$ The constitution adopted stated that the number of council members should be at least seven and at most fifteen.

${ }^{33}$ It was Josef Schumpeter who signed at the organization meeting in 1930 . The report from the meeting in Econometrica 1933 was signed by Joseph Schumpeter. Since the end of 1932, he had settled for good in the USA, although was not naturalized until 1939.

${ }^{34} \mathrm{An}$ anonymous referee has noted that Schumpeter later invited Mitchell to succeed him as president of the Econometric Society from 1942. Schumpeter had hardly changed opinion about Mitchell's suitability as council member, but this had no bearing on his courteous behavior. The society practiced having alternate US and European presidents, but Jan Tinbergen, vice-president under Schumpeter in 1940-41, was out of reach. The society was, in fact, in semi-hibernation during Mitchell's presidency in 1942-43: no meetings, no fellowship elections, and all officers and council members were re-elected.
} 
The second part of the constitution, on Members, was discussed at some length. The adopted text was as follows:

The Society shall consist of two classes of members: regular members and Fellows. Members of either class shall be subject to election. To become a regular member, a person must be proposed to the Council by two members of the Society. Once a year the Council shall nominate new members and these nominations shall be voted upon by mail by all members. No person can be elected to membership unless he is nominated by the Council.

The rules for regular membership were cumbersome. A new member had first to be proposed by two members; then the council had to approve the proposal by nominating the person for membership; and finally the vote would be effectuated in a vote by mail of all members! The vote by members was interpreted at the outset as implying unanimity in all votes cast. The constitution had a requirement for regular members"A person nominated must have sufficient knowledge of economics to be able to appreciate the work of the Society" - but it was deleted at the meeting. The adopted rules for regular membership, instead of the "admitted freely" proposed by Schumpeter, turned out in practice to cause embarrassment when a member attempted to block specific new entrants. ${ }^{35}$

The rigid rules for election of regular members can perhaps be understood as a need to protect the society from being co-opted or highly unbalanced in national composition. Some may outright have been attracted by the exclusivity of the society, implied by the power of members to block others from entering. Schumpeter's clear-sightedness gave the society the two-tiered membership that allowed active recruitment and stability.

The idea of Charter membership was retained, only to be granted during 1931. No rationale was given for why the charter membership was introduced or what eligibility for charter membership meant. Maybe the whole idea of charter members had not been sufficiently thought through.

Fellowship in the Econometric Society meant much more than a distinction bestowed on deserved members. All power was vested in the fellows, while regular members had no say. The tentative constitution dealt with election of fellows at some length, and was clearly influenced by the June letter responses:

When the Council finds it warranted, it may nominate a member for election as a Fellow. The person nominated must have been a regular member for at least one year. Each year the Council shall offer the members an opportunity to suggest names for the nomination for Fellowship. In general, a person nominated for Fellowship should satisfy the following requirements:

(1) be thoroughly familiar with general economic theory,

(2) have a working knowledge of mathematics as applied to economic theory and statistics,

\footnotetext{
${ }^{35}$ Fisher ruled in 1934 that the constitution allowed the council to name a committee to act for it in nominating candidates for membership, and recommended that it was left to the officers of the society. Fisher further advised in elections of members that it sufficed that $90 \%$ of the total vote and $90 \%$ of the vote of the candidate's fellow countrymen were in favor (November 1934, Econometric Society Minute Book, p. 19).
} 
(3) have some experience in handling statistical data,

(4) have some knowledge of accounting,

(5) have published original contributions to economic theory or to the analysis of such economic statistics, mathematics or accounting as have a definite bearing on problems in economic theory.

However, in the case of a person of great accomplishment, the Council might interpret conditions (2), (3), and (4) liberally, for instance, relaxing on conditions (3) or (4) in the case of a mathematician of high standing. Nominations for Fellows are voted on by mail by the Fellows of the Society. The first Fellows shall be elected by the Council.

The requirements for fellowship gave a somewhat bland impression of what was required to become a fellow, adding up acquired skills like Boy Scouts do. The exception clause was not unproblematic, either, and bore the mark of being a compromise. The organization meeting decided in the end on a much simpler and flexible formulation of the requirements. To be eligible for nomination for fellowship, a person "must have published original contributions to economic theory or to such statistical, mathematical or accounting analyses as have a definite bearing on problems in economic theory."

The fellowship elections were important and essential in the life of the society, as the meeting of fellows was the highest authority within the society. The number of fellows to be elected, the frequency of elections, or the voting procedure were not touched upon in the constitution. It could be argued from the constitutional importance of the fellows that the society would not be in proper constitutional order until fellows had been elected. That turned out to take almost three years, partly because the charter member issue intervened. The delay did not cause any serious detriment to the society (but a lot of worries for the president and the council members). The delay meant that the council members elected for three years at the organization meeting had their mandates renewed in 1933 for another three years by council decision instead of an election of council by fellows.

\section{AFTERMATH}

The preparation of the establishment of the Econometric Society can be viewed as having started in 1926 with what has been denoted as the Divisia-Frisch plan in this paper, and brought to fulfilment at the very end of 1930 in the low-key founding of the Econometric Society. It was not a particularly coherent process. The number of key instigators was small. No existing association or institution exerted any influence on the process or on the end result. It was a remarkable achievement. The effort of creating an international association in economics took place decades before the "internationalization" in economics and while "national schools" in economics still dominated the scene in many countries.

The solicitation of advice on how to advance the venture of founding an econometric association initiated by Irving Fisher, Ragnar Frisch, and Charles Roos through the June letter of 1930, sent to a list of thirty-one names as set out above, resulted in responses that give a picture of the situation at the time. The June letter could have been better structured and the set of respondents better chosen. After the responses to 
the June letter had been returned, a redirection of the overall project led to the foundation of the Econometric Society at an organization meeting arranged at short notice, bypassing (or rather postponing) the building up of a constituency of charter members.

The effort of founding an international econometric society around 1930 may be deemed as a venture with a considerable risk of falling by the wayside. The venture could not have succeeded without exceptional efforts by a small handful of dedicated and gifted men. But even so, it might not have succeeded without continued efforts and dedication, luck and Alfred Cowles (Bjerkholt 2013, 2015b).

After the organization meeting, the sixteen attendees scattered. There was no immediate action in the newborn society. Fisher was taken ill and did not assume the responsibilities as president until March. Schumpeter and Frisch spent the day after the meeting together, before Schumpeter left for California and Frisch went back to Yale, where he finished up the manuscript for his marginal utility book (Frisch 1932). The very last piece of work he did before leaving Yale on March 1, 1931, was to type a four-page, densely written memo "regarding steps to be taken in the organization of the Econometric Society," written in the style of instructions to Fisher about what should be done (Frisch 1931). Some points in the memo clarify issues touched upon in the article. Fisher, who had not been present at the organization meeting, was ill for about three months after the meeting.

Frisch advised that the first thing Fisher ought to do was to write a circular letterFrisch included details about what it ought to contain - to those on the "final list," by which Frisch meant the list of those who had received an invitation to the organization meeting. ${ }^{36}$ Frisch made it clear that the final list should not be confused with the "First List" or "Second List." ${ }^{37}$ Frisch impressed on Fisher that a "footnote should be added to the letter to Slutsky (who wrote that he did not think himself eligible), stating that there is now no such rigorous condition for membership as originally planned, so he would be very welcome in case he wants to join, which I.F. hopes he will." But Slutsky had a more existential reason for eluding membership. He had reason to fear for his survival; some of his colleagues, including Nikolai D. Kondratiev, had been arrested. Slutsky was high up on the list of those Frisch particularly wanted to have as members of the society.

Frisch then advised Fisher to write a letter to the elected council members, informing them officially about their election and expressing hope that they would accept. Frisch suggested that "a special and personal inducement from I.F. to E.B. Wilson should be made. Wilson was a little hesitant when R.F. asked him personally at the meeting if he would become a member of the Council. Wilson had to leave the meeting before the Council Members were elected, so he is not yet informed of his election." But Frisch had nothing to worry about: Wilson accepted and so did all the others. Thus, at the outset, there were seven council members from Europe and three from the US.

An intriguing point in the memo is the advice on how to deal with Bortkiewicz: "To Bortkiewicz it should be stated that the Society is not uniquely devoted to Mathematical Economics as he seems to believe. (See his last letter.) However, he ought to read the

\footnotetext{
${ }^{36}$ See https://www.econometricsociety.org/society/about (accessed 26 December 2016).

${ }^{37}$ Fisher kept all the names on cards, which is not surprising, as he was the original inventor of the Rolodex.
} 
Constitution and only accept the election to the Council provided he agrees with the program therein explained." Bortkiewicz had come to the conclusion that the society as founded did not have the same "devotion to mathematical economics" as the Divisia-Frisch plan. Even if Frisch might have agreed with Bortkiewicz on the facts, there was no turning back on the foundations laid by the agreement among Fisher, Schumpeter, and Frisch.

The memo had a large number of instructions for Fisher to pursue, including the election of secretary and treasurer, and the decision about membership dues. For the office of vice-president, the instruction was to propose Divisia and get him elected "with the special duty of taking care of matters of special interest to the Europeans ... with power of ... arranging a European meeting of the Society as soon as possible." A similar instruction to Fisher was to propose "that the President of the Society be given the authority to make arrangement for a meeting of the Econometric Society" in the US in December 1931. Hence, both the European and the American meetings have their origin in Frisch's memo on "steps to be taken."

The charter membership meant that it took an unreasonably long time for the society to bring its house into proper constitutional order after it was founded. The council members initiated proposals for charter members, supposed to be very well-qualified members. In practice, two (or more) council members proposed each charter member. Then it required a vote by the council to approve the membership. During 1931, 173 charter members were approved. Thus, only from 1932 could regular members be accepted.

It further delayed the first election of fellows. Eligibility for fellowship required one year's membership; thus, no election of fellows could take place until the end of 1931. It was argued and accepted, though, that the first election of fellows ought to be open also for regular members; hence, no election could take place until the end of 1932 , when the first election was indeed initiated, to be completed in August 1933. Thus, the fellows, "the highest authority of the Society," did not appear until close to three years after the founding.

Schumpeter wrote to Frisch from the Palace Hotel, San Francisco, before he boarded a ship for Japan. He suggested it was time to put the formalities aside:

Dear Frisch—let us bid goodbye to "Mr" or "Prof"-

Just a line to thank you for the copy of the letter to Mitchell. It is a masterpiece of simple and forceful exposition, and will do good. ${ }^{38} \mathrm{I}$ went straight from Cleveland to this place but left it again to enjoy $21 / 2$ days of Californian Eternal Spring in a nice place 150 miles to the south, so I had 'no time' to compose that letter to you which I wanted to write on statics and dynamics. And as I have to board my ship I shall not get very far with the subject. ... I remember with pleasure our meetings at New Haven and Cleveland. It is for me to thank you for having given me, by staying on in Cleveland, that most stimulating discussion. (Schumpeter to Frisch, January 10, 1931)

\footnotetext{
${ }^{38}$ Schumpeter referred to a recent letter from Frisch to Mitchell comprising inter alia the following passage: "it is misleading to say in a general fashion that there is only a certain sort of statistical material that will stand refined treatment, and that if the material is not of this kind it should be treated by crude methods. I would rather put it the other way around. The question is not whether the material will stand refined treatment but whether it will stand a crude treatment. ... If you will allow me to use a paradox I may say that the poorer material, the more refined must the method be" (Frisch to Mitchell, December 8, 1930).
} 


\section{SUPPLEMENTARY MATERIAL}

To view supplementary material for this article, please visit https://doi.org/10.1017/ S105383721600002X.

\section{REFERENCES}

Allen, Robert L. 1993. Irving Fisher. A Biography. Cambridge, MA: Blackwell.

1994. Opening Doors. The Life \& Work of Joseph Schumpeter. Two volumes. New Brunswick, NJ:

Transactions Publishers.

Anderson, Oskar N. 1929. Zur Problematik der empirisch-statistischen Konjunkturforschung. Bonn: Veröffentlichungen der Frankfurter Gesellschaft für Konjunkturforschung.

Bjerkholt, Olav. 1998. "Ragnar Frisch and the Foundation of the Econometric Society and Econometrica." In

Steinar Strom, ed., Econometrics and Economic Theory in the 20th Century. New York: Cambridge University Press, pp. 26-57.

— 2013. "Promoting Econometrics through Econometrica 1933-37." Available at http://papers.ssrn. com/sol3/papers.cfm?abstract_id=2401990. Accessed 27 December 2016.

_. 2015a. "Trygve Haavelmo at the Cowles Commission." Econometric Theory 31 (1): 1-84.

2015b. "How It All Began: The First Econometric Society Meeting, Lausanne, September 1931." European Journal for the History of Economic Thought 22 (6): 1149-1178. doi: 10.1080/09672567. 2015.1091853.

Bjerkholt, Olav, and Duo Qin. 2010. "Editors' Introduction.” In Olav Bjerkholt and Duo Qin, eds., A Dynamic Approach to Economic Theory. The Yale Lectures of Ragnar Frisch, 1930. London: Routledge, pp. 1-28.

Cassel, Gustav. 1924. The Theory of Social Economy. New York: Augustus M. Kelley.

Chipman, John S. 1998. "The Contributions of Ragnar Frisch to Economics and Econometrics." In Steinar Strom, ed., Econometrics and Economic Theory in the 20th Century: The Ragnar Frisch Centennial Symposium. Cambridge: Cambridge University Press, pp. 58-110.

Christ, Carl F. 1983. "The Founding of the Econometric Society and Econometrica." Econometrica 51 (1): 3-6.

Cournot, Antoine A. [1838] 1927. Researches into the Mathematical Principles of the Theory of Wealth. Translated by Nathaniel T. Bacon. With an Essay on Cournot and Mathematical Economics and a Bibliography of Mathematical Economics, by Irving Fisher. New York: Macmillan Co.

Divisia, François. 1928. L'économie rationnelle. Paris: Gaston Doin et cie.

—. 1953. "La Société d'Econométrie a Atteint sa Majorité." Econometrica 21 (1): 1-30.

Fisher, Irving. [1892] 1917. Recherches mathématiques sur la théorie de la valeur et des prix. Translated by Jacques Moret. Paris: M. Giard \& E. Brière.

- 1930a. "The Application of Mathematics to the Social Sciences." Bulletin of the American Mathematical Society 36 (4): 225-243.

1930b. The Theory of Interest. New York: Macmillan.

1933. "The Debt-Deflation Theory of Great Depressions." Econometrica 1 (4): 337-357.

Friedman, Walter A. 2009. "The Harvard Economic Service and the Problems of Forecasting." History of Political Economy 41 (1): 57-88.

Frisch, Ragnar. [1926] 1971. "On a Problem in Pure Economics.” In John S. Chipman, Leonid Hurwicz, Marcel K. Richter, and Hugo F. Sonnenschein, eds., Preferences, Utility, and Demand_A Minnesota Symposium. New York: Harcourt Brace Jovanovich, Inc., pp. 386-423. Translated by J. S. Chipman from R. Frisch. "Sur un problème d'économie pure." Norsk Matematisk Forenings Skrifter, Series 1(16).

. 1931. Note to I. F. from R. F. regarding steps to be taken in the organization of the Econometric Society. Typed memo, 4 pp., 28 February 1931.

- 1932. New Methods of Measuring Marginal Utility. Tübingen: Verlag von J. C. B. Mohr. 
1951. “Some Personal Reminiscences on a Great Man.” Econometrica 19 (2): 87-91.

1992. "From Utopian Theory to Practical Applications: The Case of Econometrics." In

A. Lindbeck, ed., Nobel Lectures, Economics 1969-1980. Singapore: World Scientific Publishing Co., pp. 9-39.

Glasner, David, ed. 1997. Business Cycles and Depressions. New York: Garland.

Haavelmo, Trygve. 1944. "The Probability Approach in Econometrics.” Econometrica 12 (Supplement, iii-vi): $1-115$.

Hendry, David F. and Mary S. Morgan, eds. 1995. The Foundations of Econometric Analysis. Cambridge: Cambridge University Press.

King, Wilford I. 1930. "The Annals of Mathematical Statistics.” The Annals of Mathematical Statistics $1(1): 1-2$.

Klausinger, Hansjoerg. 2015. "Hans Mayer, Last Knight of the Austrian School, Vienna Branch.” History of Political Economy 47 (2): 272-305.

Leonard, Robert. 2010. Von Neumann, Morgenstern and the Creation of Game Theory. From Chess to Social Science. New York: Cambridge University Press.

Louçã, Francisco. 2007. The Years of High Econometrics. London: Routledge.

Marshall, Alfred. 1936. Principles of Economics. London: Macmillan and Co.

Montesano, Aldo, Alberto Zanni, Luigino Bruni, John S. Chipman, and Michael McLure, eds. 2014. Manual of Political Economy. Vilfredo Pareto. Oxford: Oxford University Press.

Moret, Jacques. 1915. L'emploi des mathématiques en économie politique. Paris: M. Giard \& E. Brière.

Morgan, Mary S. 1990. The History of Econometric Ideas. Cambridge: Cambridge University Press.

Roos, Charles F. 1948. “A Future Role for the Econometric Society in International Statistics.” Econometrica 16 (2): 127-134.

Samuelson, Paul A. 1974. "Remembrances of Frisch.” European Economic Review 5: 7-23.

Schumpeter, Joseph A. 1954. History of Economic Analysis. London: Allen \& Unwin.

Tinbergen, Jan. 1973. "Professor Ragnar Frisch." Journal of the Royal Statistical Society Series A (General 136): 483-483.

Tobin, James. 2008. "Fisher, Irving (1867-1947)." In S. N. Durlauf and L. E. Blume, eds., The New Palgrave Dictionary of Economics. The New Palgrave Dictionary of Economics Online. Palgrave Macmillan. 24 January 2017. http://www.dictionaryofeconomics.com/article?id=pde2008_F000126. Accessed 3 February 2017. doi: 10.1057/9780230226203.0581.

Young, Allyn A. 1925: "The Trend of Economics, as Seen by Some American Economists." Quarterly Journal of Economics 39: 155-183.

Zawadzki, Wladyslaw. 1914. Les mathématiques appliquées à l'économie politique. Paris: M. Rivière et cie. 